\title{
A PROTEÇÃO JURÍDICA DO GRAFITE NO ORDENAMENTO JURÍDICO BRASILEIRO
}

\section{Clarice Fernandes Santos ${ }^{1}$}

\section{RESUMO}

O grafite evoluiu para o conceito de arte moderna e vem sendo explorado pelo mercado de consumo. No Brasil, a descriminalização do ato de grafitar contribuiu para a popularização do movimento, o que fez aumentar os conflitos envolvendo reproduções e destruições desautorizadas. O Direito ainda enfrenta problemas no tocante à tutela do grafite, tais como o seu enquadramento como arte passível de proteção pelos direitos autorais e a propriedade do suporte material. A partir de jurisprudências envolvendo o grafite, pretende-se analisar de que forma o judiciário brasileiro vem enfrentando esse fenômeno que envolve arte, cultura, cidades e direito.

Palavras-chave: Grafite. Direito da arte. Direitos Autorais. Propriedade Privada. Liberdade de expressão.

\section{THE LEGAL PROTECTION OF GRAFFITI IN THE BRAZILIAN LEGAL SYSTEM}

\section{ABSTRACT}

Graphite has evolved into the concept of modern art and has been explored by the consumer market. In Brazil, the decriminalization of graffiti has contributed to the popularization of the movement, which increased conflicts involving unauthorized reproductions and destruction. Law still faces problems in relation to the protection of graffiti, such as framing it as art subject to protection by copyright and the ownership of material support. Based on jurisprudence involving graffiti, this research intends to analyze how the Brazilian legal system has been facing this phenomenon that involves art, culture, cities and law.

Keywords: Graphite. Art law. Copyright. Private property. Freedom of expression.

\section{Introdução}

A arte de rua representa uma importante manifestação artística e cultural da contemporaneidade e vem sendo cada vez mais explorada pelo sistema capitalista, o que se cria um paradoxo: o grafite, que na teoria carrega o caráter ilegal, efêmero e anônimo, vem sendo reivindicado pelos seus autores, no tocante à tutela jurídica-estatal.

Em razão da popularização do grafite, é possível notar o aumento de disputas judiciais envolvendo a reprodução ou eliminação desautorizadas de obras. Um exemplo, é o polêmico

\footnotetext{
${ }^{1}$ Advogada e mestra em Direito Empresarial pela Fundação Mineira de Educação e Cultura (FUMEC). Especialista em Fashion Law \& Business pela Universidade Católica do Porto - PT, em 2019. Endereço eletrônico: f.clarice@ hotmail.com
} 
movimento "Cidade Limpa", criado pelo prefeito de São Paulo em 2017: nesse caso, houveram decisões absolutamente contraditórias, sendo que uma discorreu acerca da liberdade de expressão na arte de grafitar, e outra levantou a questão da ilicitudade de se utilizar propriedades privadas, sem autorização, como suporte.

O problema do presente estudo é compreender se a Lei de Direitos Autorais brasileira traz fundamentos bastantes para tutelar a arte de rua, independente do suporte escolhido pelo artista exteriorizar a sua criatividade.

Além da problemática suporte material versus obra imaterial, vigora ainda a falsa ideia de que a arte de rua é pública e, por isso, de amplo e irrestrito acesso à qualquer cidadão.

A Constituição Federal ampara as expressões artísticas e culturais, mas a própria lei que descriminalizou o grafite não garantiu proteção jurídica à arte que não seja realizada na forma legal prevista pelo $\S 2^{\circ}$ do art. $65^{\circ}$ da Lei 9.0605/1998, qual seja, aquela não autorizada pelo proprietário.

Trata-se, portanto, de uma discussão necessária, considerando o papel sócio pólitico e cultural da arte de rua e exige uma pesquisa interdisciplinar, que envolve direito, arte, cidadania e cultura.

O objetivo da presente pesquisa é analisar de que forma a jurisprudência nacional vem deliberando acerca desse conflito da contemporaneidade, que abranje arte, direitos autorais, direitos fundamentais e o parâmetro tradicional de propriedade privada.

Conforme observou Anderson Schreiber:

O problema não é inteiramente novo: tornou-se célebre nos anos 30, por exemplo, o diálogo entre Diego Rivera e Nelson Rockfeller, que mandou destruir o afresco "Man at Crossroads" por trazer o rosto de Lênin. O artista, avisado da destruição iminente da sua criação, teria exclamado "It's my painting!", ao que o segundo teria respondido "On my wall”. (SCHREIBER, 2017)

Inicialmente, investiga-se a história do grafite, sob o viés da sociologia. Posteriomente, analise-se a lei de direitos autorais brasileira, de forma a aplicá-la no universo do grafite para, ao final, discorrer acerca da titularidade do grafite e o direito à integridade da obra. 
O método de pesquisa abarcou o exame das legislações aplicáveis, além de material doutrinário e jurisprudencial.

\section{Considerações iniciais sobre o grafite}

Pintar sobre muros não é novidade. Antes as cavernas, e hoje as cidades são suportes para as manifestações artísticas do homem.

O grafite é marcado pela característica de subversão:

Subversivo, gratuito, espontâneo, efêmero, o graffiti denuncia valores sociais, desburocratiza a arte, apropria-se do espaço urbano a fim de discutir, recriar e imprimir a interferência humana na arquitetura da metrópole." (GIOVANNETTI, 2011, p. 14)

Celso Gitahy, grafiteiro e autor do livro “O que é Graffiti”, afirma em sua obra que:

O graffitar que se difunde da forma intensa nos centros urbanos é uma forma de expressão artística e humana. É impossível dissociá-la do princípio da liberdade de expressão. Tem como suporte para sua realização não somente o muro, mas a cidade como um todo. O graffiti aceita dialogar com a cidade de forma interativa. (GITAHY, 2012)

Na sentença que julgou a Ação Popular no 1004533-30.2017.8.26.0053, envolvendo grafiteiros paulistas e a Prefeitura de São Paulo, o juiz da causa inseriu o grafite ao patrimônio cultural da cidade, que deve ser visto como um processo dinâmico:

Há uma expansão do conceito de patrimônio cultural, objeto do dever de conservação pelo Poder Público Municipal, compreendendo, livre do enfoque reificado da cultura, "antropologicamente, os bens e os processos culturais, referentes às diversas identidades coletivas". (Sílvio Pinto Ferreira Junior, in Festa de Rua, Um olhar para cultura italiana em São Paulo, Editora Annablume, p. 15). Patrimônio cultural como processo, dinâmico, e não como produto, tangível. Conservam-se assim os valores de identidade de um grupo social, a sua manifestação cultural, que, no caso, denomina-se de arte urbana. Entrelaçamento desta com outras manifestações artísticas e culturais 
é evidente (Hip-hop, Rap, Skate, entre outras). A arte urbana é parte da "cultura de rua". (Processo $\mathrm{n}^{\circ}$ 1004533-30.2017.8.26.0053 - Vara de Fazenda Pública - Juiz de Direito Adriano Marcos Laroca - Julgado em 25/02/2019)

Ainda que não haja um conceito geral para a arte urbana, e ainda que recaia um preconceito sobre tal manifestação, devido à analogia com a pichação, o grafite transcende ao mero conceito de arte, mas diz respeito também à democracia, liberdade cultural, exercício da cidadania e, em última instância, efetivação da dignidade humana.

De acordo com Flávia Rezende:

O surgimento do grafite, tal como hoje é conhecido, remonta a década de 60 e início dos anos 70, nos Estados Unidos da América, mais especificamente no metrô de Nova York, onde os usuários dos trens podiam ver adolescentes com latas de spray pintando os vagões com uma postura que ARAÚJO (2011:4) descreve como de inconformismo social e político e uma tentativa de autopromoção individual ou grupal, com a construção de uma imagem diferente para a cidade. As inscrições ocupavam preferencialmente os trens, metros e muros da cidade para que fossem vistas pelo maior número de pessoas. (REZENDE, 2018, p. 22)

A arte de rua passou a ganhar espaço no cenário artístico e comercial com o passsar dos anos, com representantes como Keith Haring e Jean-Michel Basquiat, ambos referência nos Estados Unidos. No contexto britânico, a arte do misterioso artista inglês Banksy é feita com estêncil e espalhada pelo mundo, sendo fortemente marcada por críticas sociais.

No Brasil, o movimento ganhou força na cidade de São Paulo na época em que a ditatura militar condenava a liberdade de expressão e o grafite era considerado crime. Hoje, a capital é referência em arte urbana, exportando representantes mundiamente conhecidos, como Alex Vallauri, precursor do movimento no país, Os gêmeos, Eduardo Kobra, dentre outros.

O famoso bairro Wynwood em Miami, antigamente desabitado, hoje é polo turístico da cidade e contém obras de street art dos mais famosos grafiteiros da cena internacional. $\mathrm{O}$ Beco do Batman, museu a céu aberto do grafite em São Paulo, também é referência mundial. 
A arte pública, no geral, faz parte da evolução das cidades, que foram criadas, a princípio, com um intuito funcional e rígido. Hoje, todavia, os muros e paredes dialogam com a sociedade, gritam com o Estado e escancaram os problemas sociais.

A arte de rua, ao alcançar o conceito de arte moderna, sofreu uma transformação na sua própria natureza e origem ideológica. Flávia Rezende explicou essa transição:

\footnotetext{
A transição se dá, justamente, no que diz respeito aos suportes: um nítido deslocamento do espaço urbano público em direção aos interiores de ambientes privados, às peças de roupas e propagandas, onde os desenhos são dispostos livres da sujeira e da fuligem das ruas". (...) Esta transformação também está em maior ou menor escala relacionada com o deslocamento da percepção do graffiti enquanto atividade poluidora e desviante para atividade artística de vanguarda e com o desenvolvimento de um público que não reivindica nenhuma relação do estilo com a arte tradicional. (REZENDE, 2018, p. 43)
}

Assim, o grafite, que nasceu na periferia, foi absorvido pelo mercado tradicional da arte contemporânea e está sendo explorado como recurso criativo pela sociedade capitalista e transformado em bens de consumo, o que fez surgir um paradoxo: originalmente idealizado para ser anônimo, espontâneo e efêmero, os autores começaram a reivindicar a permanência, integralidade e a proteção jurídico-estatal de suas expressões artísticas.

Nesse contexto, o direito tem papel fundamental para dirimir tais conflitos.

\section{A proteção jurídica do grafite no Brasil}

$\mathrm{O}$ ato de grafitar é lícito no Brasil, todavia, a proteção legal da arte urbana enfrenta alguns problemas.

O primeiro deles está relacionado à compreensão do grafite como obra intelectual passível de proteção pela lei brasileira de Direitos Autorais (Lei 9.610/1998). A definição legal de obra intelectual é ampla, como se vê do artigo $7^{\circ}$ da lei:

Art. $7^{\circ}$ São obras intelectuais protegidas as criações do espírito, expressas por qualquer meio ou fixadas em qualquer suporte, tangível ou intangível, conhecido ou que se invente no futuro, tais como: 
VIII - as obras de desenho, pintura, gravura, escultura, litografia e arte cinética;

Além disso, ainda existe o preconceito sobre esse tipo de arte e a confusão em relação à pichação. Marco Aurélio Neto esclarece a diferença:

Pichar, segundo o Dicionário Aulete, é escrever ou desenhar sobre paredes, muros e portais. Geralmente são utilizados rolos de tinta, sprays e/ou estênceis, e comumente são pichadas frases de protestos ou marcações eassinaturas, sem fins estético-artísticos tão elaborados. Já o grafite utiliza os mesmos meios da pichação, mas objetiva um resultado artístico, seja ele estético, comunicativoou reflexivo. Visa produzir uma obra com cores, personagens, cenários e composição, gerando assim uma narrativa que critica, elogia, retrata ou distorce um elemento da realidade. É por envolver uma complexidade maior e qualidades técnicas próprias de umartista, pelo resultado em si que é alcançado, por envolver um processo criativo e um labor maior e ainda agregar valor ao ambiente, que o grafite seja considerado arte, se distanciando da pichação, sendo esta última atividade criminalizada. (NETO, 2017, pg. 689)

A Lei 12.408/2011 alterou o art. 65 da lei 9.605/98 (Lei de Crimes Ambientais) para descriminalizar o ato de grafitar, mantendo somente a pichação como conduta criminosa:

Art. 65. Pichar ou por outro meio conspurcar edificação ou monumento urbano.

Pena - detenção, de 3 (três) meses a 1 (um) ano, e multa.

$\S 1^{\circ} \mathrm{Se} \mathrm{o}$ ato for realizado em monumento ou coisa tombada em virtude do seu valor artístico, arqueológico ou histórico, a pena é de 6 (seis) meses a 1 (um) ano de detenção e multa.

$\S 2^{\circ}$ Não constitui crime a prática de grafite realizada com o objetivo de valorizar o patrimônio público ou privado mediante manifestação artística, desde que consentida pelo proprietário e, quando couber, pelo locatário ou arrendatário do bem privado e, no caso de bem público, com a autorização do órgão competente e a observância das posturas 
municipais e das normas editadas pelos órgãos governamentais responsáveis pela preservação e conservação do patrimônio histórico e artístico nacional. (grifei)

Vale ressaltar que o Código Penal, em seu art. $163^{2}$, já previa a pichação como crime de dano.

A prefeitura do Rio de Janeiro, de forma a incentivar e legitimar o ato de grafitar, expediu o Decreto Municipal 38.307/2014 e considerou que"o graffiti, desde que sem prejuízo ao patrimônio público ou histórico, sem cunho publicitário (referência a marcas ou produtos), sem teor pornográfico, racista ou de outra forma preconceituoso, sem apologias ilegais e ofensas religiosas é reconhecidamente uma manifestação artística cultural que valoriza a Cidade e inibe a pichação”.

Referido Decreto permite a utilização de espaços públicos, como postes, muros e paredes, para a prática do grafite, desde que não sejam patrimônio histórico e cultural da cidade e garantiu a permanência das obras pelo período de dois anos, desde que as intempéries do tempo, acidentes ou obras urbanas fundamentais não prejudiquem ou interfiram nos trabalhos artísticos.

Observa-se que a alteração legislativa trouxe parâmetros abolsutamente subjetivos, quais sejam, "valorização do patrimônio" e "manifestação artística", deixando à cargo da discricionariedade do poder público eleger o que é ou não arte. Contudo, é fato incontroverso que o grafite, enquanto expressão autoral original e materializada, está inserido no conceito de obra intelectual, sendo, portanto, passível de proteção pelos direitos autorais.

Os direitos autorais, que se dividem em direitos morais e materiais, tutelam um conjunto de prerrogativas do criador da obra. No tocante aos direitos morais do autor, são assegurados os direito à paternidade e integridade da obra, conforme conforme prevê o art. 24 da Lei 9.610/98:

Art. 24. São direitos morais do autor:

I - o de reivindicar, a qualquer tempo, a autoria da obra;

II - o de ter seu nome, pseudônimo ou sinal convencional indicado ou anunciado, como sendo o do autor, na utilização de sua obra;

\footnotetext{
${ }^{2}$ Art. 163 - Destruir, inutilizar ou deteriorar coisa alheia: Pena - detenção, de um a seis meses, ou multa.
} 
III - o de conservar a obra inédita;

IV - o de assegurar a integridade da obra, opondo-se a quaisquer modificações ou à prática de atos que, de qualquer forma, possam prejudicála ou atingi-lo, como autor, em sua reputação ou honra;

$\mathrm{V}$ - o de modificar a obra, antes ou depois de utilizada;

VI - o de retirar de circulação a obra ou de suspender qualquer forma de utilização já autorizada, quando a circulação ou utilização implicarem afronta à sua reputação e imagem;

VII - o de ter acesso a exemplar único e raro da obra, quando se encontre legitimamente em poder de outrem, para o fim de, por meio de processo fotográfico ou assemelhado, ou audiovisual, preservar sua memória, de forma que cause o menor inconveniente possível a seu detentor, que, em todo caso, será indenizado de qualquer dano ou prejuízo que lhe seja causado.

No tocante aos direitos materiais do autor, cabe única e exclusivamente à ele fruir ou dispor de sua obra, conforme previsão do art. $28^{3}$ da r. lei, cabendo ressaltar que a aquisição do original de uma obra, não confere ao adquirente quaisquer dos direitos patrimoniais do autor, de acordo com o art. $37^{4}$ da lei de direitos autorais.

A descriminalização do grafite representou uma evolução significativa, mas, na prática, a sua eficácia é controversa, visto que o legislador condicionou a licitude do grafite à necessidade do consentimento do dono do suporte.

Nesse contexto, é o que nos diz CONRADO (2016, p.668):

Essa medida legislativa não deixa de ser um passo importante pra a salvaguarda da arte do grafite, e vai de encontro a um ponto fundamental: se a essência da arte urbana está na transgressão e no anonimato, na subversão, na apropriação não consentida do espaço urbano, na autoria velada e na demarcação do território público/privado, faz parte de sua gênese a desnecessidade de consentimento do proprietário ou do poder público.

\footnotetext{
${ }^{3}$ Art. 28. Cabe ao autor o direito exclusivo de utilizar, fruir e dispor da obra literária, artística ou científica.

${ }^{4}$ Art. 37. A aquisição do original de uma obra, ou de exemplar, não confere ao adquirente qualquer dos direitos patrimoniais do autor, salvo convenção em contrário entre as partes e os casos previstos nesta Lei.
} 
Diante disso, tem-se o segundo problema: é possível conferir proteção autoral ao grafite concebido sem o consentimento do titular?

Enquanto o direito penal proibe as manifestações artísticas não autorizadas, o direito civil protege o autor e a obra, o que caracteriza, portanto, um conflito infraconstitucional.

Célia Lerman, em tradução de Marcelo Conrado, defende que, para a proteção autoral do grafite, basta este preencher os requisitos legais, quais sejam: originalidade e materialidade. Segundo a autora, a lei de direitos autorais norte-americana protege a intangibilidade da obra, independente se concebida de forma "ilegal", realidade plenamente aplicável ao ordenamento jurídico brasileiro.

Vejamos:

Tenho argumentado que o grafite pode ser protegido por direitos autorais (copyright). Quando uma obra de grafite cumprir os requisitos mínimos para proteção por direitos autorais (ser uma obra original, fixada em um meio tangível de expressão), a mesma deveria ser protegida por direitos autorais apesar de sua ilegalidade. Isto porque a legislação dos direitos autorais é neutra em relação a obras criadas por meios ilegais. Visto que os direitos autorais dizem respeito apenas ao aspecto intangível da obra, os mesmos não excluem obras criadas por meios ilegais. Isto se aplica mesmo se tratando de um sistema de direitos autorais baseado em incentivos, como a Lei de Direitos Autorais dos Estados Unidos (United States Copyright Act): os direitos autorais não proporcionam incentivos para a realização de atos ilegais; apenas dão incentivos para a criação de obras artísticas de valor, independentemente dos meios utilizados para criá-la. (CONRADO, 2016)

A Lei de Direitos Autorais brasileira sequer declara expressamente que a ilegalidade é um obstáculo à proteção, bastando os requisitos previstos pela legislação, quais sejam, originalidade e exteriorização em um suporte físico.

Diante disso, pode-se afirmar que o aspecto intangível da obra pode ser protegido pelo direito autoral, considerando que a Lei 9.610/98 não exclui obras criadas por meios ilegais.

Há quem diga ainda que a arte de rua não foi feita para durar, o que eliminaria os direitos à integridade e conservação da obra intelectual. 
Contudo, a efemeridade do grafite, que de fato estará sempre sujeito às trajédias climáticas e até à intervenção de outros artistas, não pode ser critério para nergar-lhe proteção.

Nesse sentido, ponderou Anderson Schreiber:

\begin{abstract}
A efemeridade do grafite está relacionada a transformações realizadas no espaço urbano no interesse útil da coletividade (por exemplo, demolição do muro grafitado para instalação de um parque ou passagem de uma nova avenida) ou no seu interesse cultural (realização de outros grafites ou novas expressões de contracultura), não já de intervenções puramente eliminatórias como a polêmica pintura de cinza. (SCHREIBER, 2017)
\end{abstract}

A "polêmica pintura de cinza" citada pelo autor, diz respeito ao movimento "Cidade Limpa", criado pela prefeitura de São Paulo, em 2017, para "limpar" os grafites e pichações da cidade, resultando na destruição do maior mural a céu aberto da América Latina.

A liminar foi concedida, todavia, o agravo de instrumento interposto pela Prefeitura de São Paulo foi provido, sob o seguinte entendimento:

Não há dúvida que as manifestações artísticas, como é o caso do grafite, merecem toda proteção do Poder Público, conforme assegura a Constituição Federal. Po outro lado, não se pode perder de vista que incumbe ao próprio Poder Público exercer o poder de polícia ambiental e implementar políticas públicas para zelar pela paisagem urbana. No caso da cidade de São Paulo tais políticas são justificadas à vista das pichações, que se evidenciam verdadeiros atos de vandalismo espalhados por toda a cidade. (TJSP - AI no 20290219420178260000 - 6 Câmara de Direito Privado - Relatora Maria Olívia Alves - DJE 22/08/2017) (grifei)

É possível verificar a contradição no voto da relatora, que ao mesmo tempo que reconhece a proteção das manifestações artísticas pela Constituição Federal, confere ao Muncípio a soberania para distinguir grafites de pichações, o que, conforme dito, culminou na destruição de diversas obras de arte. 
Em sentença de mérito, o magistrado rejeitou completamente a conduta discricionária do poder público e defendeu a liberdade de expressão dos artistas, em minuciosa e brilhante decisão:

\section{A arte urbana não é efêmera, é dinâmica, como todo ou qualquer bem ou processo cultural imaterial. Efêmero é o suporte físico de sua expressão visual. (grifei)}

O desejo individual, mesmo que compartilhado por um grupo social, contrário a essa manifestação cultural, vendo-a como poluição visual, não poderá ser sopesado pelo Estado Brasileiro, como garantidor do exercício da liberdade como valor supremo de uma sociedade fraterna, pluralista e sem preconceitos, fundada na harmonia social. Esse modo de pensar, sutil e supostamente também fundado na liberdade, revela um certo autoritarismo, uma profunda desconsideração social à liberdade de ser e pensar do outro. Uma sociedade plural, democrática, exige, na ordem pública (no comum inclusive), que o exercício da liberdade de um cidadão não exclua ou amesquinhe o exercício da liberdade de outro. Um direito impõe um dever a outro, e vice-versa.

Em tempos lineares de censura à liberdade cultural provocada pela confusão entre o público e o privado, é necessário dizer que as vontades, os desejos, os preconceitos, os valores particulares do cidadão não devem pautar a ação política-administrativa do Estado, assim como este, camuflado daqueles, não deve interferir no processo de criação ou manifestação artística, entre outras liberdades civis. Dirigismo cultural, de qualquer espectro político, já sabemos no que dá." (Processo no 1004533-30.2017.8.26.0053 - 12 ${ }^{\mathrm{a}}$ Vara de Fazenda Pública de São Paulo - Juiz de Direito Adriano Marcos Laroca Julgado em 25/02/2019)

Diante desse caso concreto, está-se diante da terceira problemática: tem o detentor do suporte físico direitos sobre a obra?

A liberdade de expressão, bem como o direito à cultura, são direitos fundamentais previstos pela Constituição Federal: 
Art. $5^{\circ}$ Todos são iguais perante a lei, sem distinção de qualquer natureza, garantindo-se aos brasileiros e aos estrangeiros residentes no País a inviolabilidade do direito à vida, à liberdade, à igualdade, à segurança e à propriedade, nos termos seguintes:

IX - é livre a expressão da atividade intelectual, artística, científica e de comunicação, independentemente de censura ou licença; (grifei)

Art. 215, CF. O Estado garantirá a todos o pleno exercício dos direitos culturais e acesso às fontes da cultura nacional, e apoiará e incentivará a valorização e a difusão das manifestações culturais.

Art. 216. Constituem patrimônio cultural brasileiro os bens de natureza material e imaterial, tomados individualmente ou em conjunto, portadores de referência à identidade, à ação, à memória dos diferentes grupos formadores da sociedade brasileira, nos quais se incluem:

I - as formas de expressão;

II - os modos de criar, fazer e viver;

III - as criações científicas, artísticas e tecnológicas;

IV - as obras, objetos, documentos, edificações e demais espaços destinados às manifestações artístico-culturais;

V - os conjuntos urbanos e sítios de valor histórico, paisagístico, artístico, arqueológico, paleontológico, ecológico e científico.

$\S 1^{\circ}$ O Poder Público, com a colaboração da comunidade, promoverá e protegerá o patrimônio cultural brasileiro, por meio de inventários, registros, vigilância, tombamento e desapropriação, e de outras formas de acautelamento e preservação. (grifei)

Merece destaque ainda o art. 220 do diploma constitucional:

Art. 220. A manifestação do pensamento, a criação, a expressão e a informação, sob qualquer forma, processo ou veículo não sofrerão qualquer restrição, observado o disposto nesta Constituição. 
De outro lado, tem-se o Direito Civil e a noção clássica da propriedade privada, que tem sido relativazada em atenção à sua função social. Ou seja, a jurisprudência tem considerado não só os interesses do particular, mas também daqueles que gravitam além dos muros.

O próprio $\S 1^{\circ}$ do art. 1.228 do Código Civil, o qual trata dos direitos de propriedade, se preocupou em proteger os direitos da coletividade:

Art. 1.228. O proprietário tem a faculdade de usar, gozar e dispor da coisa, e o direito de reavê-la do poder de quem quer que injustamente a possua ou detenha.

$\S 1^{\circ} \mathrm{O}$ direito de propriedade deve ser exercido em consonância com as suas finalidades econômicas e sociais e de modo que sejam preservados, de conformidade com o estabelecido em lei especial, a flora, a fauna, as belezas naturais, o equilíbrio ecológico e o patrimônio histórico e artístico, bem como evitada a poluição do ar e das águas.

Nesse contexto, Flávia Rezende pondera acerca da relativização da propriedade privada:

Convém uma observação importante nos poderes de disposição do domínio facultados ao proprietário, na medida em que não se trata de dar aos não proprietários o direito de compartilharem do uso, da fruição e da disposição da coisa, porque estes poderes são inerentes e exclusivos do proprietário, mas, de enxergar que a coletividade deve exigir o cumprimento da função social. Se assim não fosse, sairíamos do absolutismo privado do proprietário para uma coletivização do direito de propriedade. Não é isso. O que se pretende é ver respeitados os limites reais e interesses do proprietário no que concerne as produções artísticas que recobrem as paredes e muros da propriedade. (REZENDE, 2018)

A liberdade de expressão deve ser garatinda pela função social da propriedade, ou seja, os artistas são livres para criar, contando que não causem prejuízos à terceiros. Além disso, o prejuízo de um proprietário que recebe uma obra de arte não é simples de comprovar, sendo certo que, no geral, ocorre a valorização do imóvel. 
Deve ser levado em conta ainda que os muros externos de uma propriedade, em geral, não têm qualquer utilidade para o dono.

Conclui-se que, em que pese a legislação exigir a permissão do titular do suporte para criação da obra, caso haja o descumprimento da função social da propriedade, os direitos de dono deixam de existir, em prol da integridade da arte e do direito coletivo de tê-la incorporada na cidade.

É uma "obrigação" social que o proprietário tem que "suportar", já que uma obra de arte tem mais valor para o coletivo do que o interesse particular. Ademais, impedir a liberadade criativa do artista, significa abalar a sua diginidade. Nesse sentido:

Neste contexto, a Constituição Federal, seja pelo reconhecimento da liberdade cultural como direito fundamental (artigo 5o, IX) seja pela gestão comunitária da política cultural (artigo 216, parágrafo 1o), resguarda a diversidade de culturas (todas as manifestações da cultura brasileira têm a mesma hierarquia e status de dignidade perante o Estado), como princípio constitucional garantidor do pluralismo cultural (artigo 215 caput e artigo 216-A, parágrafo 1o, I), essencial ao exercício sadio da cidadania e, em última instância, efetivação da dignidade humana. Todos são fundamentos do Estado Democrático de Direito (artigo 1o, II, III e V). Daí a fundamentalidade dos direitos culturais acima, com suas conhecidas consequências jurídicas eficácia plena, aplicabilidade imediata e prioridade na efetivação. (Processo $\mathrm{n}^{\circ}$ 100453330.2017.8.26.0053 - Vara de Fazenda Pública - Juiz de Direito Adriano Marcos Laroca - Julgado em 25/02/2019) (grifei)

Por fim, o último problema diz respeito ao caráter público da arte do grafite. Eduardo Vieira Manso diz que "as obras de artes que estiverem nesses locais podem ser livremente reproduzidas, pois é presumível que seu autor, ao entregá-la ao povo, abandonou seus direitos patrimoniais sobre ela." (MANSO, 1980).

O art. 48 da Lei 9610/98 assim dispõe: 
Art. 48. As obras situadas permanentemente em logradouros públicos podem ser representadas livremente, por meio de pinturas, desenhos, fotografias e procedimentos audiovisuais.

Este mesmo artigo antes continha a expressão "reproduzidas", agora substituída por "representadas", que possuem significados distintos, conforme bem explicou o desembargador Enio Zuliani, no julgamento do seguinte caso:

É nítido que a legislação brasileira vigente, ao alterar a expressão anterior "reprodução" para "representação", visou suprimir, das utilizações permitidas para obras intelectuais situadas permanentemente em logradouro público, a modalide ("reprodução") anteriormente liberada. Assim, apenas a representação da obra pelos meios indicados estaria retirada da órbita dos direitos autorais a serem regularmente exercidos pelo autor; em outras palavras, a ninguém estaria vedado representar em uma pintura ou em um desenho a obra de escultura protegida e a ninguém estaria venda a sua representação, também por meio fotográfico ou audiovisual.

A distinção de "reprodução" e "representação" embora possa parecer simples, possui particularidades que justificam algumas palavras. Reproduzir é distribuir cópias em larga escala e fica mais grave quando se faz com o intuito de lucro. Para reproduzir não há como dispensar autorização do autor. Representar, contudo, significa utilizar em perspectiva ou desenhar, fotografar para deleite ou para finalidade ilustrativa e deverá ser entendido que ilustrar uma campanha publicitária explorando a obra situada em local público, como um calendário ou qualquer outro peça informativa sem superposição de fotos ou arranjos, constitui uso indevido, caso se for realizada sem licença do autor. (TJSP - APELAÇÃO $n^{\circ}$ 103408479.2015.8.26.0100 - 30 Câmara Extraordinária de Direito Privado Relator(a): Enio Zuliani - DJE 02/03/2018)

Portanto, o art. 48 deve ser conjugado com os artigos 77 e 78 da Lei 9.610/98: 
Art. 77. Salvo convenção em contrário, o autor de obra de arte plástica, ao alienar o objeto em que ela se materializa, transmite o direito de expô-la, mas não transmite ao adquirente o direito de reproduzi-la.

Art. 78. A autorização para reproduzir obra de arte plástica, por qualquer processo, deve se fazer por escrito e se presume onerosa.

A lei confere a liberdade de representar obras exibidas em local público, mas o sentido da "liberdade" há que ser associado com os direitos assegurados nas normas supracitadas.

Se o intuito é comercial, de forma direta ou indireta, a hipótese não é a do art. 48, mas a dos arts. 77 e 78: quando uma arte é utilizada para ilustrar um produto que será comercializado por um terceiro para obtenção de lucro, sem a devida autorização do autor, há violação dos direitos autorais.

Concluindo, a reprodução puramente ilustrativa de obra situada em local público prescinde de autorização prévia do autor, considerando que a sua divulgação contribui com a evolução cultural e social da cidade. Contudo, a reprodução da obra para fins comerciais, diretos ou indiretos, exige a prévia anuência do autor.

\section{Jurisprudência brasileira}

A jurisprudência envolvendo a arte de rua ainda é escassa, mas é possível analisar de que forma os Tribunais brasileiros vem interpretando o assunto.

A revista de moda Vogue Brasil utilizou a imagem de um grafite para ilustrar um ensaio fotográfico, localizado no "Beco do Batman", todavia, a editora indicou a autoria do grafite à terceiro diverso do real autor, que acionou o Judiciário pleiteando indenização por danos morais e materiais.

Em primeira instância, o processo foi julgado improcedente, sob o entendimento de que a citação errônea do artista, não viola direitos autorais. Em sede recursal, a apelação interposta pelo grafiteiro Frederico Georges de Barros Day foi parcialmente provida para condenar a apelada ao pagamento de indenização por danos morais, no valor de $\mathrm{R} \$ 20.000,00$.

$\mathrm{O}$ relator negou o pedido de danos materiais, sob o fundamento de que, ainda que o grafite tenha embelezado a fotografia, a campanha não tinha caráter publicitário, mas tão somente artístico. Além disso, entendeu pela acessoriedade do grafite em relação ao foco da campanha, que não associou a obra com a roupa vestida pela modelo. 
De outro lado, julgou presente o dano moral, sob o entendimento de que "a atribuição da paternidade da obra artística a outrem é modalidade de dano moral in re ipsa."

$\mathrm{O}$ relator considerou abusiva a conduta de atribuir a paternidade de obra à terceiro, mormente quando seria possível fazê-lo com segurança, considerando tratar-se de conhecida revista, fazendo alusão a uma experiência parecida vivida pelo artista Michelângelo:

Até Michelângelo testemunhou algo semelhante com o trabalho realizado por encomenda eclesiástica (uma Pietá de mármore em que a musculatura do corpo de Cristo ganhou contornos típicos e próprios do artista italiano), porque consta que ao entrar um dia na capela onde a obra estava exposta escutou de pessoas que admiravam o trabalho que teria sido produto não dele (Michelangelo), mas, sim de "Gobbo, de Milão". No livro de Giorgio Vasari (Vida de Michelangelo Buonarroti, tradução de Luiz Marques, Editora Unicamp, 2011, p. 85) está escrito: "Michelângelo ficou quieto, mas the pareceu estranho que seus trabalhos fossem atribuídos a outros. Uma noite trancou-se na capela com uma luzinha e, tendo trazido os cinzéis, ali entalhou seu nome". Seria essa a única obra assinada (o nome foi escrito de través em uma cinta de que o peito de Nossa Senhora se cinge e fez constar: Michael.Angelus.Bonarotus.Florent.Faciebati. (TJSP - Apelação $n^{\circ}$ 103408479.2015.8.26.0100 - DES. PEDRO CORRÊA LIAO - DJE 27/02/2018)

A loja de departamento Riachuelo foi condenada a indenizar o artista Francisco Rodrigues da Silva, pela indevida utilização de parte de sua obra localizada na galeria "The Wynwood Arts District”, em Miami, na campanha primavera-verão 2011/2012, como pano de fundo tanto em catálogo quanto em filme publicitário.

O juiz da causa observou que não houve qualquer pedido de autorização, tampouco a indicação da autoria e o grafite foi modificado com a sobreposição da marca. Assim, foi arbitrada indenização por danos morais e materiais, considerando o caráter publicitário da campanha. A sentença foi confirmada em segunda instância, com majoração dos danos morais:

\footnotetext{
${ }^{5}$ TJSP - Apelação no 103408479.2015.8.26.0100 - DES. PEDRO CORRÊA LIAO - DJE 27/02/2018
} 
“APELAÇÃO. DIREITO AUTORAL. OBRA ARTÍSTICA. Pleito ajuizado por artista em face de empresa, ao argumento de que esta utilizou sua obra artística indevidamente em campanha publicitária. Sentença de procedência, com condenação da ré ao pagamento de indenização por danos materiais, os quais deverão ser apurados em sede de liquidação por arbitramento. Condenação da ré, ainda, ao pagamento de indenização por danos morais decorrentes da não indicação de autoria da obra artística. Apelo do autor. Consistência. Sentença que não considerou a utilização do grafite arte de autoria do apelante, pela requerida, em filme publicitário. Conteúdo divulgado no Youtube e no site da apelada. Nítida finalidade comercial. Autor que também deverá ser indenizado pelos danos materiais decorrentes do uso de sua obra no filme publicitário. Ausência de indicação da autoria da obra artística no filme publicitário que consubstancia dano moral do autor, consoante a Lei $\mathrm{n}^{\circ}$ 9.610/98. Majoração do valor dos danos morais de $\mathrm{R} \$$ $10.000,00$ para $\mathrm{R} \$ 25.000,00$, notadamente porque a utilização do grafite no filme publicitário foi maior do que no catálogo de fotografias, além de conter alteração digital da obra do apelante. RECURSO PROVIDO”. (TJSP - APELAÇÃO No 0037387-55.2014.8.26.0100 - Relator Viviani Nicolau $3^{\text {a }}$ Câmara de Direito Privado - 19/02/2019).

A revista brasileira VIP utilizou uma arte de grafite como pano de fundo para um editorial de moda, sem indicar a titularidade do autor ou requerer autorização para tanto, sendo condenada a indenizar o artista.

A revista se defendeu com base no art. 48 da Lei 9.610/98, que prevê que as obras situadas em logradouros públicos podem ser representadas livremente.

Todavia, equivocada a tese de defesa, conforme esclarecido anteriormente e reconhecimento pelo relator da apelação:

A obra de arte colocada em logradouro da cidade, que integra o patrimônio público, gera direitos morais e materiais para o seu autor quando utilizado indevidamente foto sua para ilustrar produto comercializado por terceiro, que sequer possui vinculação com área turística ou cultural."

E pouco importa para a proteção dos direitos autorais, se a obra foi dada a lume em logradouro público. A Constituição da República, art. $5^{\circ}$, XXVII, 
preconiza a proteção ao trabalho artístico, não faz a cerebrina distinção pretendida pela ré. Como se vê, é dada com exclusividade aos autores o direito de exploração da obra. E nem se diga que estando a obra exposta em local público, devolve ao domínio público a sua titularidade, retirando do artista seu direito exclusividade na captação de haveres com a sua utilização. Seria o mesmo que, guardadas as devidas proporções, negar a Michelangelo a autoria dos afrescos da capela Sistina, somente porque feitos em local de visitação pública intensa. Nítida na espécie a intenção da embargante de se utilizar do desenho como um "plus" de suas mercadorias, com insofismável interesse mercantil. (TJSP - Apelação n ${ }^{\circ} 10052213320138260020$ - Relator Salles Rossi - DJE 31/05/2017)

O relator ainda bem observou que se o graffiti não agregasse valor ao material publicitário e, consequentemente, aos produtos veiculados, não teria a revista elegido justamente o local onde se situa a obra artística para servir de pano de fundo para a campanha de moda.

Assim, foi arbitrada indenização de cunho moral e material, visto que o grafite serviu à ilustração de produto comercializado por terceiro para obtenção de lucro e sem a devida autorização, agravado pelo fato de não ter havido sequer alusão ao nome do artista, revelando a afronta ao direito autoral do mesmo.

\section{Conclusão}

A popularização do grafite e o seu crescente aproveitamento pelos meios comerciais e industriais vem ampliando a abordagem jurídica da arte de rua no Brasil, que tem ganhado uma jurisprudência simpatizante.

O intuito da presente pesquisa é fomentar a discussão doutrinária acerca da proteção jurídica do grafite, para que reflita na indústria, no comércio, no poder público e na sociedade em geral, de forma a impedir reiteradas violações dos direitos autorais dos artistas de rua.

Ainda que o grafite tenha sido descriminalizado, o que caracterizou um avanço para a sua tutela jurídica, a lei permanece subjetiva no tocante ao conceito da arte de rua. Além disso, na prática, a eficácia da lei ainda é controversa, uma vez que a licitude do grafite está condicionada à necessidade de anuência do proprietário do suporte físico. De toda forma, 
conforme concluiu-se, a lei de direitos autorais protege a obra de arte original e materializada, independente da sua legalidade.

No tocante ao conflito entre a titularidade do suporte físico, a função social da propriedade deve ser considerada de modo a privilegiar o direito da coletividade, desde que não haja prejuízos à terceiros.

Conclui-se que a efemeridade do grafite não impede a sua proteção legal, visto que o que é finito é o suporte físico da manifestação artística, ou seja, a tutela do grafite ultrapassa a materialidade do visual, caracterizando um aspecto cultural intangível.

Liberdade de expressão, direito à cultura e direito à propriedade privada, considerando a sua função social, são direitos fundamentais que devem coexistir de forma harmoniosa para se construir uma cidadania e democracia plena e justa.

Independente das predileções e gostos individuais, seja de um particular ou do Estado, a dignidade da pessoa humana proporciona ao homem a liberdade de criar e aos cidadãos o pleno exercício dos direitos culturais. E assim, a arte de rua vai sobrevivendo.

\section{Referências Bibliográficas}

ALGARVE, João Henrique Kurtz Amantino Rodrigues da Silva. O copyright, o direito de autor e seus reflexos no Direito Internacional Privado. Trabalho de conclusão de curso apresentado na Universidade Federal do Rio Grande do Sul. Porto Alegre, 2010;

BUSHATSKY, José. Direito Autoral. São Paulo, 1980, pg. 300;

CARTAXO, Zalinda. Arte nos espaços públicos: a cidade como realidade. O Percevejo. Periódico do Programa de pós-graduação em Artes Cênicas. UNIRIO, 2009;

CONRADO, Marcelo Miguel. A arte nas armadilhas dos direitos autorais. Tese apresentada como requisito para aobtenção do título de Doutor em Direito pela PósGraduação, Setor de Ciências Jurídicas da Universidade Federal do Paraná. Curitiba, 2013;

FILHO, Marcílio Toscano Franca. O grafite e a preservação de sua integridade: A pele da cidade e o "droit au respect" no direito brasileiro e comparado. Revista de Direito da Cidade, vol. 08, $\mathrm{n}^{\mathrm{o}}$ 4, 2016;

NETO, Bruno Pedro Giovannetti. Graffiti: do subversivo ao consagrado. Tese ao Programa de Pós-Graduação em Arquitetura e Urbanismo pela Universidade de São Paulo. 2011, p. 14;

GITAHY, C. O que é Graffiti. São Paulo: Brasiliense, 2012; 
LERMAN, Celia. Protecting artistic vandalism: Graffiti and Copyright Law.

Forthcoming, NYU Journal of Intellectual Property and Entertainment Law, 2012;

NETO, Bruno Pedro Giovannetti. Graffiti: do subversivo ao consagrado. Tese ao Programa de Pós-Graduação em Arquitetura e Urbanismo pela Universidade de São Paulo. 2011. pg. 14;

NETO, Marco Aurélio Mayer Duarte; LUCCA, Petri Tomaz Felinto. A tela urbana: A proteção jurídica ao grafite no direito brasileiro e comparado. RDL - Rede Brasileira de Direito e Literatura, Anais do V CIDIL, V. 5, N. ${ }^{\circ}$ 2, Julho/2017;

REZENDE, Flávia Romano. A tutela da arte de rua na perspectiva do direito autoral. Dissertação apresentada como requisito para obtenção do título de Mestre em Direito pela Universidade Estácio de Sá. Rio de Janeiro, 2018;

RIBEIRO, Gisele. Da arte pública à esfera pública política da arte. Revista Poiésis, n. 20, p. 33-44. Dezembro de 2012;

SCHREIBER, Anderson. O Dano-Cinza. Disponível em http://www.cartaforense.com.br/conteudo/colunas/o-dano-cinza/17341. consult. em 26/03/2020;

TARTUCE, Flávio. O Dano Cinza. Disponível em https://flaviotartuce.jusbrasil.com.br/artigos/430975053/o-dano-cinza, consult. em 26/03/2020;

VIEIRA MANSO, Eduardo. Direito Autoral. 1a ed., São Paulo: Bushatsky, 1980. 